\title{
Accelerated uptake by phytoplankton of iron bound to humic acids
}

\author{
Min Chen, Wen-Xiong Wang* \\ State Key Laboratory of Marine Environmental Science, Department of Oceanography, Xiamen University, Fujian, 361005 \\ PR China, and Department of Biology, The Hong Kong University of Science and Technology (HKUST), Clear Water Bay, \\ Kowloon, Hong Kong, SAR
}

\begin{abstract}
Most of the dissolved iron (Fe) in seawater is complexed by organic ligands. One key issue in understanding Fe limitation in the sea is the bioavailability of different forms of Fe to marine phytoplankton. We measured Fe uptake by the coastal diatom Thalassiosira pseudonana and the cyanobacterium Synechococcus sp., using model ligands desferrioxamine B (DFB) and ferrichrome (FC), humic acids (HA), and natural organic matter of high molecular weight (HMW). We also determined the Fe binding capacity of organic matter in different size fractions. The order of the initial assimilation rates of different Fe species was: inorganic Fe $\geq \mathrm{HA}-\mathrm{Fe}(\mathrm{III})>\mathrm{DFB}-\mathrm{Fe}(\mathrm{III}) \approx \mathrm{FC}-\mathrm{Fe}(\mathrm{III})$. The high bioavailability of HA-bound Fe(III) implies that humic substances are important not only in controlling Fe geochemical behavior, but also in providing Fe for marine phytoplankton, especially in estuarine and coastal waters. Fe assimilation rates decreased with increasing Fe binding capacity of various types of organic matter, and with increasing molar ratio of organic matter to Fe(III), suggesting that the ultimate form of Fe(III) utilized by phytoplankton is the exchangeable inorganic Fe(III). By separating the uptake media from the phytoplankton, we demonstrated that the organic-bound Fe was first absorbed onto the cell surfaces and exchanged Fe into the specific surface sites before Fe internalization. Fe-depleted diatoms assimilated Fe much faster than Fe-replete diatoms, thus the Fe transport system is regulated by the nutritional status of the cells. Overall, our study showed the important role of iron-binding ligands in controlling Fe bioavailability to marine phytoplankton; it is necessary to evaluate the relative importance of various organic ligands for biological uptake of Fe.
\end{abstract}

KEY WORDS: Iron · Organic complexation · Uptake · Marine diatoms · Marine cyanobacteria Resale or republication not permitted without written consent of the publisher

\section{INTRODUCTION}

Phytoplankton growth, which can be limited by the availability of $\mathrm{Fe}$, plays a key role in the global carbon cycle, such as the primary productivity, the sea-air $\mathrm{CO}_{2}$ flux, and the export of organic carbon (Boyd 2004). Fe is an essential micronutrient for phytoplankton, as well as virtually for all other organisms, because of its varied functions in biological redox processes, including transport of oxygen, assimilation of inorganic nitrogen compounds, electron transport, and oxygen insertion reactions. However, ferric ion, which was thought to be the major source of Fe in biological systems, is quantitatively insoluble as hydroxide at natural $\mathrm{pH}$. Dissolved Fe concentrations in the surface open ocean are at sub-nanomolar levels (e.g. $0.37 \mathrm{nM}$ in the Cen- tral North Pacific, Bruland et al. 1994; <0.1 nM in the Northeast Pacific, Martin \& Gordon 1988). In coastal environments, although inputs of both $\mathrm{Fe}$ and natural organic matter are often much higher, most of the Fe is removed from the water column as ferric oxyhydroxide (Sholkovitz et al. 1978), therefore Fe may still be scarce from a biological perspective.

Most of the dissolved Fe in seawater is complexed with organic ligands (Rue \& Bruland 1995, 1997, Wu \& Luther 1995). In the open ocean, organic compounds with extremely high selectivities and affinities for ferric iron (siderophores and unidentified compounds with similar properties) bind $>99 \%$ of the organically complexed iron (Rue \& Bruland 1995, 1997, van den Berg 1995, Wu \& Luther 1995, Nolting et al. 1998). In coastal environments, natural organic matter is abun- 
can form complexes with iron (Rose \& Waite 2003). Recently, 2 main types of Fe-binding organic ligands have been identified and most ligands were in the colloidal fractions (0.03 0.4 $\mu \mathrm{m}$ ) (Buck et al. 2007). Humic substances (humic and fulvic acids) contribute to iron complexation, keeping iron in a soluble form at both high $\mathrm{pH}$ and high concentrations of anions and cations in estuarine systems (Hering \& Morel 1988). Humic substances are also able to stimulate the growth of coastal phytoplankton in laboratory cultures (Graneli \& Moreira 1990, Carlsson \& Graneli 1993, Kosakowska et al. 2007) and contribute to the phytoplankton bloom in coastal waters (Glover 1978).

Recent evidence demonstrated the importance of humic substance in complexing $\mathrm{Fe}$ in coastal and oceanic seawater (Rose \& Waite 2003, Tani et al. 2003, Takata et al. 2004), but little is known about the bioavailability of humic substance-bound Fe. Kuma et al. (1999) determined the short-term assimilation rates of organic-bound Fe by the diatom Chaeoceros sociale and found that $\mathrm{Fe}$ bound to humic substance is more available than EDTA-Fe(III).

Fe bound with siderophore desferrioxamine B (DFB) can be utilized by marine diatoms and natural phytoplankton communities (Soria-Dengg \& Horstmann 1995, Hutchins et al. 1999a, Maldonado \& Price 1999), but some studies have indicated that siderophorebound $\mathrm{Fe}$ cannot be taken up by marine diatoms (Kuma et al. 2000, Nodwell \& Price 2001, Timmermans et al. 2001a,b), and the addition of DFB can reduce the biological uptake of $\mathrm{Fe}$ and the growth rate of phytoplankton (Hutchins et al. 1999a, Wells 1999, Wells \& Trick 2004). Hutchins et al. (1999a) further suggested that marine eukaryotic phytoplankton more rapidly assimilated porphyrin-complexed Fe while prokaryotic picoplankton more rapidly assimilated the siderophore complexes. However, due to different molar ratios of organic ligand to Fe [5:1 and 10:1 in Hutchins et al. 1999a; 2:1 and 10:1 in Kuma et al. 2000; and 100:1 and 1000:1 in Nodwell \& Price 2001], it is difficult to compare the results. Besides, only a few studies have considered the assimilation of organic-complexed Fe by marine cyanobacteria. Wilhelm \& Trick (1994) examined the effects of siderophores on Fe uptake in Synechococcus PCC 7002, and found that Fe assimilation was faster than without added siderophore, in both Fereplete and Fe-deficient cells. Hutchins et al. (1999a) found that the uptake of siderophore-bound Fe by prokaryotic phytoplankton was faster than or similar to that of inorganic Fe. Poorvin et al. (2004) determined Fe assimilation rates from bacterial lysate, cyanobacterial lysate, EDTA-bound $\mathrm{Fe}$ and inorganic $\mathrm{Fe}$ by the laboratory cultures of Thalassiorira pseudonana and Synechococcus sp. PCC7002, and concluded that prokaryotic and eukaryotic organisms can assimilate
Fe released from the lysis of both heterotrophic and autotrophic marine plankton. Recently, Salmon et al. (2006) measured the rates of iron uptake by the cyanobacterium Lyngbya majuscula in the presence of a variety of model- and naturally-derived organic ligands, and proposed a new kinetic model to describe the iron acquisition via nondissociative reduction of ferric complexes.

Two major Fe transport systems have been proposed to describe Fe uptake. (1) A siderophore-based system in which the cells secrete strong Fe(III)-binding chelators into the external environment and transport the Fe(III) complex into the cell (Trick 1989, Wilhelm \& Trick 1994, Wilhelm 1995). (2) ferrous or ferric ion membrane transporters that bind with external $\mathrm{Fe}(\mathrm{II})$ or $\mathrm{Fe}(\mathrm{III})$ following ligand exchange with labile $\mathrm{Fe}$ species (Anderson \& Morel 1982, Hudson \& Morel 1990, Sunda \& Huntsman 1995). It is not clear which mechanism is more important for the uptake of organic Fe complexes (Salmon et al. 2006).

In previous studies, we found that Fe bound with natural colloids was indeed biologically available (Chen \& Wang 2001, Chen et al. 2003, Wang \& Dei 2003). In this study, we determined the initial Fe assimilation rates from different model ligand complexes by Fe-depleted and Fe-replete marine phytoplankton. Siderophores (a low molecular weight organic matter) and humic acid (a high molecular weight organic matter) were chosen to represent the possible organic ligands that bind $\mathrm{Fe}(\mathrm{III})$ in natural seawaters. We compared the bioavailability of inorganic $\mathrm{Fe}(\mathrm{III})$, siderophore-bound Fe(III), humic acid-bound Fe(III) to the coastal diatom Thalassiosira pseudonana and cyanobacteria Synechococcus sp., and examined the relationship between the bioavailability of different organic Fe complexes and the Fe binding capacity with model and natural organic compounds. We further investigated the effects of the molar ratio of organic ligand to Fe on the bioavailability of Fe(III) complexed by these model ligands. Furthermore, we studied whether ligand exchange at the cell surface was important for the uptake of organic complexed Fe by marine phytoplankton.

\section{MATERIALS AND METHODS}

Measurement of Fe binding capacity. Fe binding capacities with different organic ligands were assessed by determining Fe solubility in the presence of these compounds, using methods described in Chen et al. (2004). Siderophores DFB and FC (both from Sigma) and HA (Aldrich) were used as representative low molecular weight (LMW) and high molecular weight (HMW) organic ligands, respectively. Seawater col- 
lected from Clear Water Bay, Hong Kong (salinity of 34) was passed through a $0.2 \mu \mathrm{m}$ Poretics cartridge, and then ultrafiltered using a spiral-wound cross-flow ultrafiltration cartridge (Amicon S10Y3) with a $3 \mathrm{kDa}$ molecular weight cutoff (Guo \& Santschi 1996, Guo et al. 2000). The integrity of the ultrafiltration cartridge was evaluated by using fluorescein tagged $10 \mathrm{kDa}$ dextran. The retention efficiency of our ultrafiltration cartridge for this high molecular weight substance was $95 \%$. Aliquots of the ultrafiltered seawater $(<3 \mathrm{kDa}$, LMW) were sequentially treated by UV irradiation (450 W, ACE UV lamp, Model 7480) to remove natural dissolved organic matter. Decrease of DOC concentration during UV irradiation was monitored to ensure that the organic matter in the seawater was destroyed completely. Our previous experiments demonstrated that $91 \%$ of the background $\mathrm{Fe}$ was removed by Chelex 100 resin (Chen et al. 2004). In the current experiments, the DOC-free LWM seawater was therefore passed through the Chelex 100 resin twice to ensure that $99 \%$ of the background Fe was removed.

After ultrafiltration, the retentate (high molecular weight, HMW) and permeate solution (LMW) were used for measurement of the Fe binding capacity. For the retentate solution, diafiltration was carried out immediately after ultrafiltration to remove LMW organic matter. The Fe- and DOC-free LMW seawater was used as the de-salting solution. Loss of the HMW (>3 kDa) organic carbon during diafiltration was $17 \%$. The purified HMW and LMW solutions were again passed through the Chelex 100 resin to remove background Fe.

Fe binding capacity was determined by a ${ }^{59} \mathrm{Fe}$ radiotracer technique. Ligand was added into Fe- and DOCfree LMW seawater in a Teflon bottle to a final DOC concentration of $50 \mu \mathrm{M}$. Radioactive ferric ${ }^{59} \mathrm{Fe}(\mathrm{New}$ England Nuclear) solution was spiked with a predetermined amount of stable ferric Fe and added to the LMW seawater containing the organic matter. A predetermined amount of $1 \mathrm{~N} \mathrm{NaOH}$ was added to keep the $\mathrm{pH}$ constant. The final nominal Fe concentration after Fe addition was $10 \mathrm{nM}$. LMW seawater without organic compound addition was used as control. For each treatment, a $3 \mathrm{ml}$ sample was first taken for the determination of the initial total ${ }^{59} \mathrm{Fe}$ radioactivity. All treatments were then kept in the dark at room temperature. At $2 \mathrm{~h}$, a $3 \mathrm{ml}$ sample aliquot was filtered through either a $0.2 \mu \mathrm{m}$ filter (Whatman), a $10 \mathrm{kDa}$ centrifugal membrane, or a $3 \mathrm{kDa}$ centrifugal membrane (Millipore). In addition, another $3 \mathrm{ml}$ sample was taken for total ${ }^{59} \mathrm{Fe}$ measurement. The samples were acidified with $0.5 \mathrm{ml}$ of $1 \mathrm{~N} \mathrm{HCl}$ to prevent possible adsorption of $\mathrm{Fe}$ (III) onto the collecting vials. ${ }^{59} \mathrm{Fe}$ radioactivity in the total sample and the filtrates was measured by gamma spectrometry. There were 2 replicate bottles for each treatment.
Dissolved Fe concentration was calculated from the radioactivity counts, the volume of solution in the vial, and the Fe specific activity. Assuming that dissolved Fe concentration in the control treatment only resulted from inorganic Fe solubility, the size-fractionated Fe binding capacity (nmol Fe per mmol organic carbon) was calculated from the difference between Fe solubility in seawater containing organic compounds and that in the control treatment. Fe binding capacity represents the total Fe bound by different organic compounds in a certain time $(2 \mathrm{~h})$. Since the organic matter consisted of a mixture of compounds with different affinities for $\mathrm{Fe}$, the Fe binding capacity represents an average affinity.

Organic ligands and phytoplankton. Stock solutions of DFB, FC and HA were first prepared by using Feand DOC-free CWB LMW seawater. ${ }^{59} \mathrm{Fe}$ in $0.01 \mathrm{~N} \mathrm{HCl}$ was added to each ligand solution at different molar ratios. A predetermined amount of $1 \mathrm{~N} \mathrm{NaOH}$ was added to keep the $\mathrm{pH}$ constant and allowed to equilibrate overnight in the dark at $4{ }^{\circ} \mathrm{C}$. Molar ratios ranged from 1:5 to 1:1000 (Fe:ligand) for the Fe-DFB complex, 1:5 to $1: 5000$ (Fe:carbon) for $\mathrm{Fe}-\mathrm{HA}_{\text {; }}$ for Fe-FC, only a molar ratio of 1:200 (Fe:ligand) was tested. Since the binding capacity of $\mathrm{HA}$ and natural organic matter (LMW and HMW) with Fe was low (see 'Results'), some of the added Fe may have precipitated as particulate Fe.

The two species of phytoplankton used in the uptake experiments were the coastal diatom Thalassiosira pseudonana and a representative of oceanic picoplankton, Synechococcus sp. (CCMP 1334). Both were obtained from the Provasoli-Guillard Phytoplankton Collection Center and maintained in $f / 2$ medium (Guillard \& Ryther 1962) in axenic cultures at $18^{\circ} \mathrm{C}$. Cells were used in the exponentially growing phase. To obtain Fe-depleted diatoms, cells grown in $f / 2$ medium were collected and resuspended in Fe- and DOC-free LMW seawater, to which the major nutrients, vitamin B12 and trace metals (except Fe) were added. Nutrients were passed through Chelex 100 resin before they were used. To minimize the intracellular Fe pool, cells were collected and resuspended in Fe-free medium. A total of 4 transfers were conducted over a period of $7 \mathrm{~d}$, and the last transfer was performed $2 \mathrm{~d}$ before the experiments. For Synechococcus sp., there was no major difference in cell growth between Fe-replete and Fe-depleted cells in the Fe- and DOC-free LMW seawater, due to their very low cellular Fe demands (Sunda \& Huntsman 1997). Thus, only Synechococcus sp. acclimatized to the Fe-free LMW seawater were used in our experiments.

Measurements of Fe uptake. Phytoplankton cells were filtered onto a polycarbonate membrane, rinsed with Fe- and DOC-free LMW seawater, and distrib- 
uted into $150 \mathrm{ml} \mathrm{Fe-} \mathrm{and} \mathrm{DOC-free} \mathrm{LMW} \mathrm{seawater} \mathrm{in}$ an acid-clean polycarbonate bottle. The initial density of the cells was $3 \times 10^{4}$ cells $\mathrm{ml}^{-1}$ for Thalassiosira pseudonana, and $2 \times 10^{6}$ cells $\mathrm{ml}^{-1}$ for Synechococcus sp. A control treatment with heat-killed dead cells was also prepared to evaluate the residual Fe amount after washing with $\mathrm{Ti}(\mathrm{III})$-EDTA-citrate reagents (Hudson \& Morel 1989). There were 2 replicate bottles for each experimental treatment. All experiments were conducted on a Class-100 clean bench to minimize contamination.

A short-term (8 h) exposure was conducted in media containing organically complexed Fe or ${ }^{59} \mathrm{Fe}(\mathrm{III})$ (as inorganic $\mathrm{Fe}$ ) directly spiked into the medium. Feorganic complexes with different Fe:ligand ratios or inorganic Fe were added at a final concentration of $2.3 \mathrm{nM}$. A $3 \mathrm{ml}$ sample was taken for the determination of the initial ${ }^{59} \mathrm{Fe}$ radioactivity. The cells were then incubated at a light illumination of $70 \mu \mathrm{mol} \mathrm{m} \mathrm{m}^{-2} \mathrm{~s}^{-1}$ at $18^{\circ} \mathrm{C}$. At different times of the exposure, samples were taken for cell density measurements using a Coulter counter. A $5 \mathrm{ml}$ water sample was removed and acidified for measurement of ${ }^{59} \mathrm{Fe}$ radioactivity. A $15 \mathrm{ml}$ water sample was filtered onto a $1 \mu \mathrm{m}$ polycarbonate membrane, rinsed with $\mathrm{Ti}(\mathrm{III})$ reagents (Hudson \& Morel 1989) for $2 \mathrm{~min}$, and then further rinsed with LMW seawater. The filter (representing the intracellular ${ }^{59} \mathrm{Fe}$ ) and the Ti-washing and LMW-washing solutions were then measured for radioactivity. All samples for ${ }^{59} \mathrm{Fe}$ measurements were acidified with $0.5 \mathrm{ml}$ of $1 \mathrm{~N} \mathrm{HCl}$ to prevent possible adsorption of $\mathrm{Fe}(\mathrm{III})$ onto the collecting vials. As the surface area of cells is important for biological Fe uptake and differences existed among experiments, the intracellular Fe uptake rate was normalized to surface area. The intracellular $\mathrm{Fe}$ amount, $\mathrm{Fe}_{\text {intrar }}$ at each time point was calculated using Eq. (1):

$$
\mathrm{Fe}_{\text {intra }}=\frac{\left[{ }^{59} \mathrm{Fe}\right]_{t}}{\left[{ }^{59} \mathrm{Fe}\right]_{0}} \cdot\left[\mathrm{Fe}_{\mathrm{a}}\right]_{0} /\left(C_{t} \cdot S\right)
$$

where $\left[{ }^{59} \mathrm{Fe}\right]_{t}$ and $\left[{ }^{59} \mathrm{Fe}\right]_{0}$ are activity of ${ }^{59} \mathrm{Fe}$ at times $t$ and 0, respectively, $\left[\mathrm{Fe}_{\mathrm{a}}\right]_{0}$ is the initial Fe concentration $(2.3 \mathrm{nM}), C_{t}$ is the cell density (cells $\left.\mathrm{ml}^{-1}\right)$ at time $t$, and $S$ is the surface area per cell $\left(\mu \mathrm{m}^{2} \mathrm{cell}^{-1}\right)$.

For both the siderophore-based transport system used by cyanobacteria (Wilhelm \& Trick 1994) and the membrane transport system used by diatoms (Anderson \& Morel 1982, Hudson \& Morel 1990, Sunda \& Huntsman 1995), Fe uptake kinetics consist of 2 steps: (1) initial reversible binding of $\mathrm{Fe}$ species to transport sites or carriers, and (2) irreversible transport into the cell (Hudson \& Morel 1993, Santana-Casiano et al. 1997). According to Hudson \& Morel (1993) and SantanaCasiano et al. (1997), the change of transport complex concentration can be described as:

$$
\frac{\mathrm{d}[\mathrm{FeL}]}{\mathrm{d} t}=\mathrm{k}_{\mathrm{f}}\left[\mathrm{Fe}^{\prime}\right]\left[\mathrm{L}^{\prime}\right]-\left(\mathrm{k}_{\mathrm{d}}+\mathrm{k}_{\mathrm{in}}\right)[\mathrm{FeL}]
$$

where $\left[\mathrm{Fe}^{\prime}\right],\left[\mathrm{L}^{\prime}\right]$, and $[\mathrm{FeL}]$ represent the concentra-

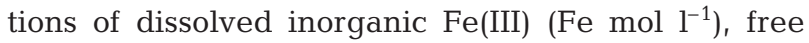
transport ligand $\mathrm{L}$ not bound to $\mathrm{Fe}\left(\mathrm{Fe} \mathrm{mol} \mathrm{m}^{-2}\right)$, and Fe bound to surface transport ligands ( $\mathrm{Fe} \mathrm{mol} \mathrm{m}^{-2}$ ), respectively; $\mathrm{k}_{\mathrm{f}}, \mathrm{k}_{\mathrm{d}}$, and $\mathrm{k}_{\mathrm{in}}$ represent rate constants for Fe'complexation by $\mathrm{L}\left(\mathrm{L} \mathrm{mol}^{-1} \mathrm{~h}^{-1}\right)$, FeL dissociation $\left(\mathrm{h}^{-1}\right)$, and internalization of Fe from FeL $\left(\mathrm{h}^{-1}\right)$, respectively. If $\left[\mathrm{Fe}_{\text {intra }}\right]=0$ at $t=0$, the solution for Eq. (2) becomes:

$$
\begin{gathered}
\Delta[\mathrm{FeL}]_{\text {in }}=\rho_{0} \tau\left(1-\mathrm{e}^{-t / \tau}\right) \\
\tau=\frac{1}{\mathrm{k}_{\mathrm{d}}+\mathrm{k}_{\mathrm{in}}}
\end{gathered}
$$

where $[\mathrm{FeL}]_{\text {in }}$ is concentration of intracellular $\mathrm{Fe}, \rho_{0}$ $\left(=\mathrm{k}_{\mathrm{in}}[\mathrm{FeL}]_{0}\right)$ is the initial $\mathrm{Fe}$ assimilation rate at $t=0$ (Fe mol $\mu \mathrm{m}^{-2} \mathrm{~h}^{-1}$ ), and $\tau$ is the mean residence time (h) of Fe in the FeL complex.

Values of $\rho_{0}$ were obtained by regression of the $8 \mathrm{~h}$ time series measurements. The non-linear uptake pattern reflects the variability of assimilation rates during the experimental period, due to changes in metabolism in the cells during Fe uptake or changes in bioavailability of Fe species. However, the initial Fe assimilation rate can be obtained by regression of the non-linear data. Intracellular Fe concentration does not change linearly during incubation (Anderson \& Morel 1982, Hudson \& Morel 1990, Santana-Casiano et al. 1997, Maldonado \& Price 1999, Hutchins et al. 1999b, Kuma et al. 1999, 2000, Chen et al. 2003, Wells \& Trick 2004). According to Tailor's expansion, the exponential function in Eq. (3) can be changed to a linear function when $(-t / \tau)$ is small enough, i.e. the variability of [FeL] due to internalization and dissociation processes is small.

Fe uptake of natural organic complexes. To test whether the Fe complexed with HMW organic ligands was first dissociated into the solution and then available for uptake by the diatom, we conducted another uptake experiment by physically separating the Feligand complexes from the diatom. Natural HMW substances isolated from CWB seawater and HA were used as the organic ligands, and only Fe-depleted Thalassiosira pseudonana was used in the experiments. To obtain Fe in the HMW complexed form, ${ }^{59} \mathrm{Fe}$ was first added to the HMW or HA solution contained in a dialysis bag (3 $\mathrm{kDa}$ cutoff). The final concentration of Fe was $2.3 \mathrm{nM}$, and the concentrations of $\mathrm{HA}$ and HMW were $422 \mu \mathrm{M}$ and $20 \mu \mathrm{M}$, respectively, and the $\mathrm{pH}$ was adjusted to 8 . By suspending in Fe- and DOC-free LMW seawater, any uncomplexed ${ }^{59} \mathrm{Fe}$ was removed by replacing the surrounding LMW seawater every 12 h (Chen \& Wang 2001, Chen et al. 2003). After 2 to $3 \mathrm{~d}$, there was a negligible amount of ${ }^{59} \mathrm{Fe}$ released 
into the LMW seawater. The HMW solution labeled by ${ }^{59} \mathrm{Fe}$ was then transferred into a new dialysis bag ( $3 \mathrm{kDa}$ cutoff), and placed into the Fe- and DOC-free LMW seawater containing the Fe-depleted diatom; HMW- or HA-bound Fe contained in the dialysis bag was thus not in direct contact with the cells. Total ${ }^{59} \mathrm{Fe}$ content in the uptake media and the intracellular ${ }^{59} \mathrm{Fe}$ were measured. In the control treatment, the HMW- or HA-bound Fe was directly added into the media without the barrier of the dialysis bag.

Quality control, radioactivity, and organic carbon measurements. ${ }^{59} \mathrm{Fe}$ washed by Ti-reagents or adsorbed onto the bottles was measured throughout the experiments to quantify the Ti-washing efficiency and the mass balance. DOC concentration was measured using a total organic carbon analyzer (Shimazu TOC Vcph). Radioactivity of ${ }^{59} \mathrm{Fe}$ was measured by a Wallac 1480 gamma counter at $1092 \mathrm{keV}$. Counting time was adjusted to ensure that statistical errors in counting were $<10 \%$ (most were $<5 \%$ ).

\section{RESULTS}

\section{Fe binding capacity by different ligands}

The calculated Fe binding capacities of siderophores (DFB and FC), HA, and natural organic matter (HMW and LMW) are shown in Table 1. The total Fe binding capacities $(<0.2 \mu \mathrm{m})$ decreased from $\sim 200 \mathrm{nmol}$ $\mathrm{mmolC}^{-1}$ for siderophores to $4 \mathrm{nmol} \mathrm{mmolC}^{-1}$ or less for the other compounds. Siderophores and HA had higher affinity than natural organic matter. Most of the complexed Fe occurred in the $<3 \mathrm{kDa}$ fraction in DFB and $\mathrm{FC}$, in the $3 \mathrm{kDa}-0.2 \mu \mathrm{m}$ fraction in the case of $\mathrm{HA}$, HMW and LMW. These partitioning characteristics were consistent with the physiochemical properties of the organic matter. Generally, siderophores have a molecular weight $<1 \mathrm{kDa}$ (Winkelmann 1991), and are capable of binding $\mathrm{Fe}(\mathrm{III})$ with high affinity and specificity (Chen et al. 2004). In contrast, HA has a molecular weight $>1 \mathrm{kDa}$, and is capable of binding with trace metals by complexation (Mantoura et al. 1978). In the case of LMW $(<3 \mathrm{kDa})$, the high amount of complexed $\mathrm{Fe}$ in the fractions $>3 \mathrm{kDa}$ may be due to the secondary formation of HMW organic matter after Fe addition.

\section{Fe uptake by Synechococcus sp.}

The kinetics of biological Fe uptake $\left(\rho_{0}\right)$ by Synechococcus sp. is shown in Fig. 1 and Table 2. A much lower intracellular ${ }^{59} \mathrm{Fe}$ level was detected in heatkilled cells during $8 \mathrm{~h}$ exposure to FC-Fe and HA-Fe (Fig. 1b,d), indicating that Ti(III)-washing was efficient in removing extracellular Fe from the cells. Overall, assimilation rates of siderophore-bound Fe were 10 to $100 \times$ slower than those of HA-Fe and inorganic Fe. Over the $8 \mathrm{~h}$ exposure period, $>150 \times 10^{-21} \mathrm{~mol} \mathrm{\mu m}^{-2}$ of Fe was accumulated for inorganic Fe and HA-Fe at molar ratios up to 1000:1 (ligand:Fe), whereas $<6 \times$

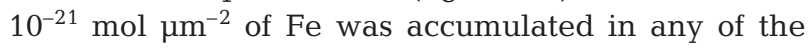
FC-Fe and DFB treatments. Fe uptake generally decreased with increasing molar ratio, in both the DFBFe and HA-Fe treatments. (Fig. 1c,d).

\section{Fe uptake by Fe-depleted and Fe-replete diatoms}

To test whether the medium was Fe deficient, a growth experiment was performed using Thalassiosira pseudonana. After about 5 d, Fe limitation occurred and the cell numbers were about one-third of those in Fe-replete media (Fig. 2). Cell growth resumed when $10 \mathrm{nM}$ Fe was added to the culture. Cell sizes under

Table 1. Size-fractionated Fe binding capacities of different organic ligands (nmol bound Fe per mmol organic carbon); data are mean (\%). DFB: desferrioxamine B; FC: ferrichrome; HA: humic acids; HMW: Clear Water Bay high molecular weight; LMW: Clear Water Bay low molecular weight $(<3 \mathrm{kDa})$

\begin{tabular}{|lcccr|}
\hline & $<3 \mathrm{kDa}$ & 3 to $10 \mathrm{kDa}$ & $\begin{array}{c}10 \mathrm{kDa} \\
\text { to } 0.2 \mu \mathrm{m}\end{array}$ & Total \\
\hline DFB & $207(88)$ & $32(12)$ & $-4(0)$ & $235(100)$ \\
FC & $201(96)$ & $11(4)$ & $-2(0)$ & $210(100)$ \\
HA & $2(4)$ & $18(38)$ & $27(58)$ & $47(100)$ \\
HMW & $0.4(10)$ & $0.4(10)$ & $3.6(80)$ & $4.4(100)$ \\
LMW & $2.0(20)$ & $2.6(27)$ & $5.2(53)$ & $9.8(100)$ \\
\hline
\end{tabular}

Table 2. Synechococcus sp. CCMP 1334 and Thalassiosira pseudonana. Assimilation rates $\left(\rho_{0}\right.$, in $\left.10^{-21} \mathrm{~mol} \mathrm{Fe} \mu \mathrm{m}^{-2} \mathrm{~h}^{-1}\right)$ of $2.3 \mathrm{nM} \mathrm{Fe}$ by cyanobacteria and Fe-depleted and -replete diatoms. FC: ferrichrome; DFB: desferrioxamine B; HA: humic acids

\begin{tabular}{|lcccc|}
\hline Fe species & $\begin{array}{c}\text { Molar ratio } \\
\text { ligand:Fe }\end{array}$ & $\begin{array}{c}\text { Synecho- } \\
\text { coccus }\end{array}$ & $\begin{array}{r}\text { T. pseudonana } \\
\text { Fe-depleted }\end{array}$ & Fe-replete \\
\hline Inorganic Fe & - & 42.1 & 291 & 57 \\
FC-Fe & $200: 1$ & 0.5 & 3 & 0 \\
DFB-Fe & $5: 1$ & 0.7 & 18 & - \\
& $10: 1$ & 0.6 & 12 & - \\
& $50: 1$ & 0.5 & 8 & - \\
& $200: 1$ & 0.5 & 10 & - \\
HA-Fe ${ }^{\text {a }}$ & $1000: 1$ & 0.5 & 8 & - \\
& $5: 1$ & 36.7 & 234 & 57 \\
& $50: 1$ & 42.4 & 221 & 51 \\
& $200: 1$ & 37.1 & 156 & 60 \\
a Molar ratio is organic C:Fe & & 166 & 55 \\
& $1000: 1$ & 20.6 & 109 & 45 \\
& $5000: 1$ & 5.7 & & \\
\hline
\end{tabular}



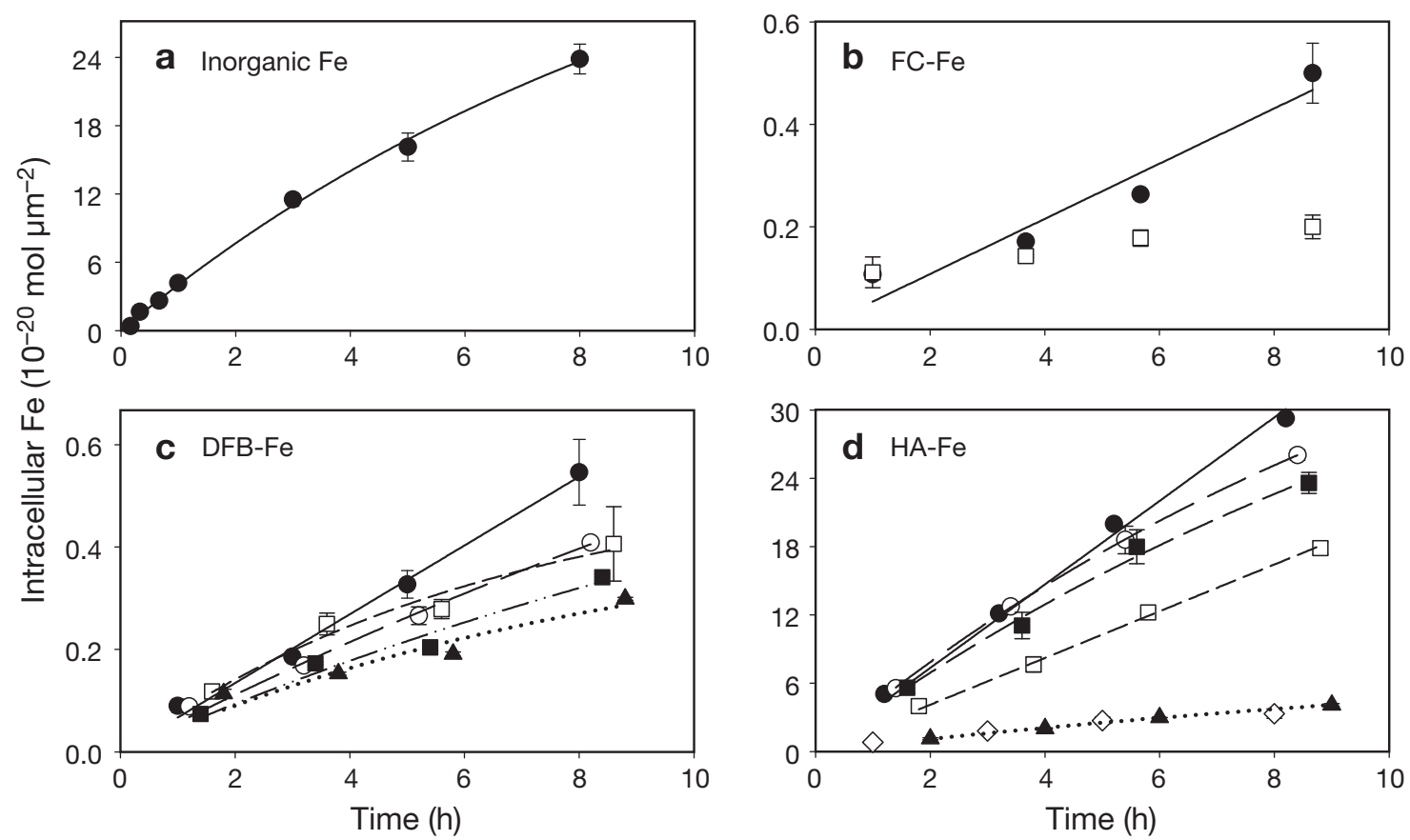

Fig. 1. Synechococcus sp. CCMP 1334. Intracellular uptake of Fe. (a) Inorganic Fe. (b) FC-Fe (ligand:Fe molar ratio 200:1); (•):

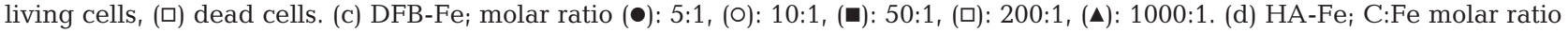

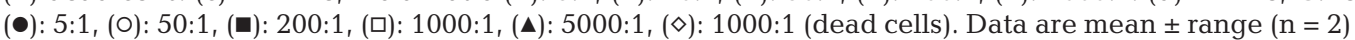

Fe-replete and -depleted conditions were 5.0 and $3.5 \mu \mathrm{m}$, respectively, as measured under the microscope. Uptake of organic Fe complexes by Fe-depleted and -replete diatoms is shown in Table 2 and Figs. 3 \& 4. Intracellular Fe uptake by Fe-depleted diatoms was 1 order of magnitude higher than in Synechococcus sp. Inorganic $\mathrm{Fe}$ and $\mathrm{Fe}$ complexed with $\mathrm{HA}$ was again taken up much faster than Fe complexed with DFB and FC. In the case of inorganic Fe(III), intracellular Fe increased rapidly during the first hour and then stabilized (Fig. 3a). The high concentration of inorganic Fe(III) represents the actual instantaneous availability of Fe for uptake although the hydrolytic precipitation rate of $\mathrm{Fe}^{3+}$ in seawater is extremely fast. Over the $8 \mathrm{~h}$

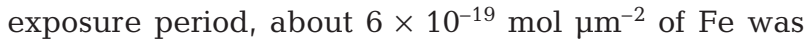
taken up in the inorganic Fe and HA-Fe treatments,

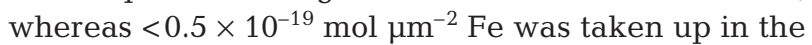
$\mathrm{FC}$ and DFB treatments. Intracellular Fe accumulation decreased with increasing molar ratio of ligand:Fe (Fig. 3). Fe assimilation rates $\left(\rho_{0}\right)$ were fastest for the inorganic Fe and HA-Fe (Table 2).

Intracellular Fe in Fe-replete diatoms was lower than that in dead cells for the DFB and FC treatments (Fig. $4 \mathrm{~b}, \mathrm{c})$, indicating that the former did not utilize Fe from siderophore-bound Fe. The lower intracellular Fe in the living cells was due to increasing cell density as
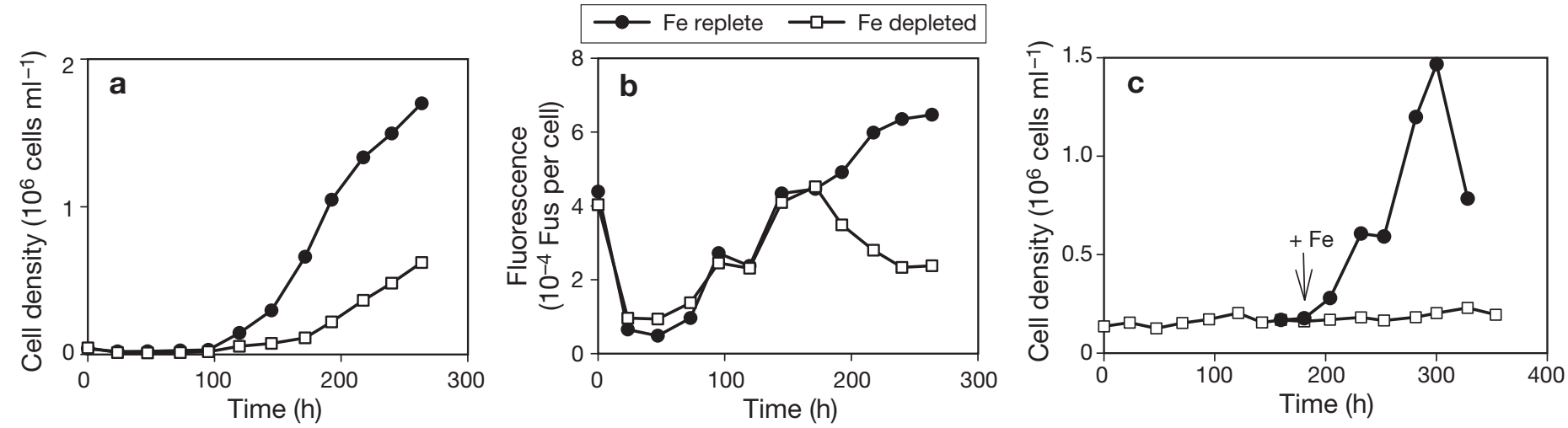

Fig. 2. Thalassiosira pseudonana. Growth in Fe-replete (450 nM) and Fe-depleted medium. (a) cell density; (b) fluorescence per cell; (c) cell growth of Fe-depleted diatoms following addition of $10 \mathrm{nM}$ inorganic Fe(III) 

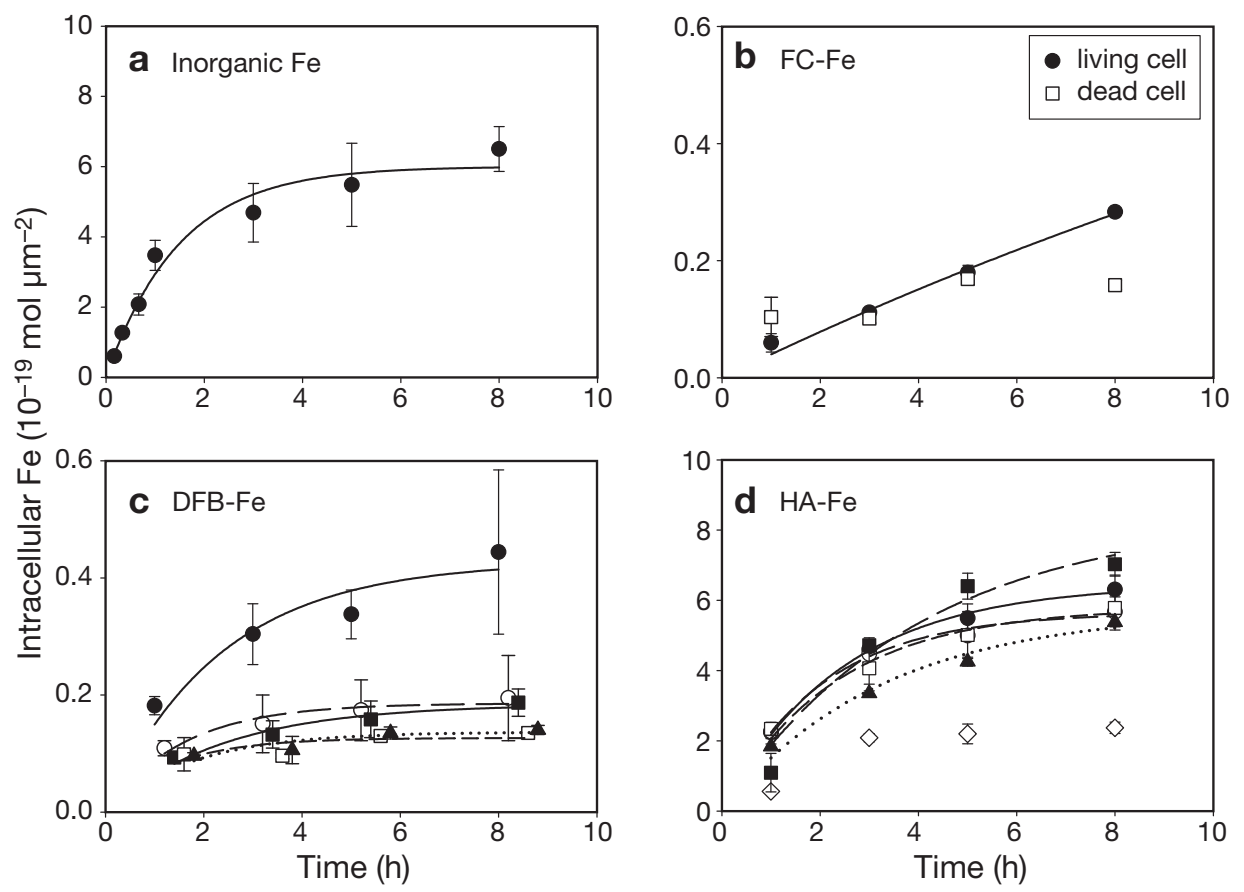

Fig. 3. Thalassiosira pseudonana. Intracellular uptake of Fe by Fe-depleted cells. (a) Inorganic Fe. (b) FC-Fe (ligand:Fe molar

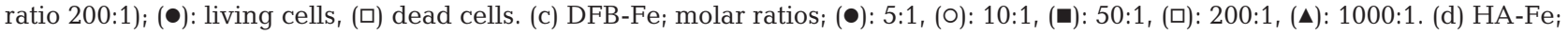

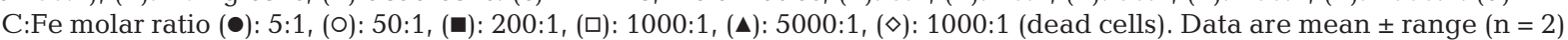

a result of diatom growth. Inorganic Fe and HA-Fe were taken up by Fe-replete diatoms, but their intracellular fractions were lower that those in Fe-depleted diatoms. Uptake of HA-Fe was independent of molar ratio (Fig. 4d). Assimilation rate $\rho_{0}$ of $\mathrm{HA}-\mathrm{Fe}$ and inorganic $\mathrm{Fe}$ by the Fe-replete diatoms was roughly one-third of that in Fe-depleted diatoms (Table 2).

\section{Fe uptake from high molecular weight complexes}

Using a dialysis bag, we compared Fe uptake by diatoms with and without direct contact to HA- and HMW-bound Fe (Fig. 5). Intracellular Fe uptake was consistent with the results obtained for Fe-depleted diatoms (Fig. 3). When the organic-bound Fe was separated from the diatoms by a dialysis bag, intracellular Fe uptake was 1 order of magnitude lower.

\section{DISCUSSION}

\section{Uptake of different Fe species by phytoplankton}

The order of uptake of different Fe species was as follows: inorganic $\mathrm{Fe} \geq \mathrm{HA}-\mathrm{Fe}>\mathrm{DFB}-\mathrm{Fe} \approx \mathrm{FC}-\mathrm{Fe}$, and was consistent for different molar ratios of organic ligands to Fe, phytoplankton species, and the nutritional status of the cells. The initial assimilation rate of inor- ganic Fe (at $2.3 \mathrm{nM} \mathrm{Fe}$ ) was $4.2 \times 10^{-20} \mathrm{~mol} \mathrm{Fe} \mu \mathrm{m}^{-2} \mathrm{~h}^{-1}$ for Synechococcus sp., which is 61 to $109 \times$ faster than those observed by Hutchins et al. (1999a) for Synechococcus sp. CCMP 1334 and Synechococcus sp. PCC 7002 (at 5 to $10 \mathrm{nM}$ ), but $10 \times$ slower than those observed by Trick \& Wilhelm (1995) for Synechococcus sp. PCC 7002 (at 5.1 nM). However, our Fe assimilation rates were calculated based on non-linear regression, whereas the earlier studies were typically based on a single measurement at the end of the exposure, assuming that a steady state had been attained. The initial assimilation rates of siderophore-bound Fe (DFB and FC) varied slightly among different molar ratios of organic ligand, and were similar to those obtained by Hutchins et al. (1999a) ( 2 to $9 \times 10^{-22} \mathrm{~mol} \mathrm{Fe} \mu \mathrm{m}^{-2} \mathrm{~h}^{-1}$ at 5 to $10 \mathrm{nM} \mathrm{Fe}$, with a ratio of ligand:Fe of $5: 1$ ). When the molar ratios of HA-C to Fe were $<200: 1$, the initial assimilation rates of HA-bound Fe by Synechococcus sp. $\left(\sim 4 \times 10^{-20} \mathrm{~mol} \mathrm{Fe} \mu \mathrm{m}^{-2} \mathrm{~h}^{-1}\right)$ were similar to those of inorganic Fe, suggesting high bioavailabilty of HA-Fe. However, when the molar ratio of HA-C to Fe increased to 1000:1 and 5000:1, initial Fe assimilation rates decreased substantially.

The initial Fe assimilation rates in Synechococcus sp. were slower than those in diatoms Thalassiosira pseudonana; assimilation rates of HA-Fe were similar to those of inorganic $\mathrm{Fe}$ in the case of both species (Table 2). The high bioavailability of HA-Fe to diatoms is consistent with Kuma et al. (1999), who found that 

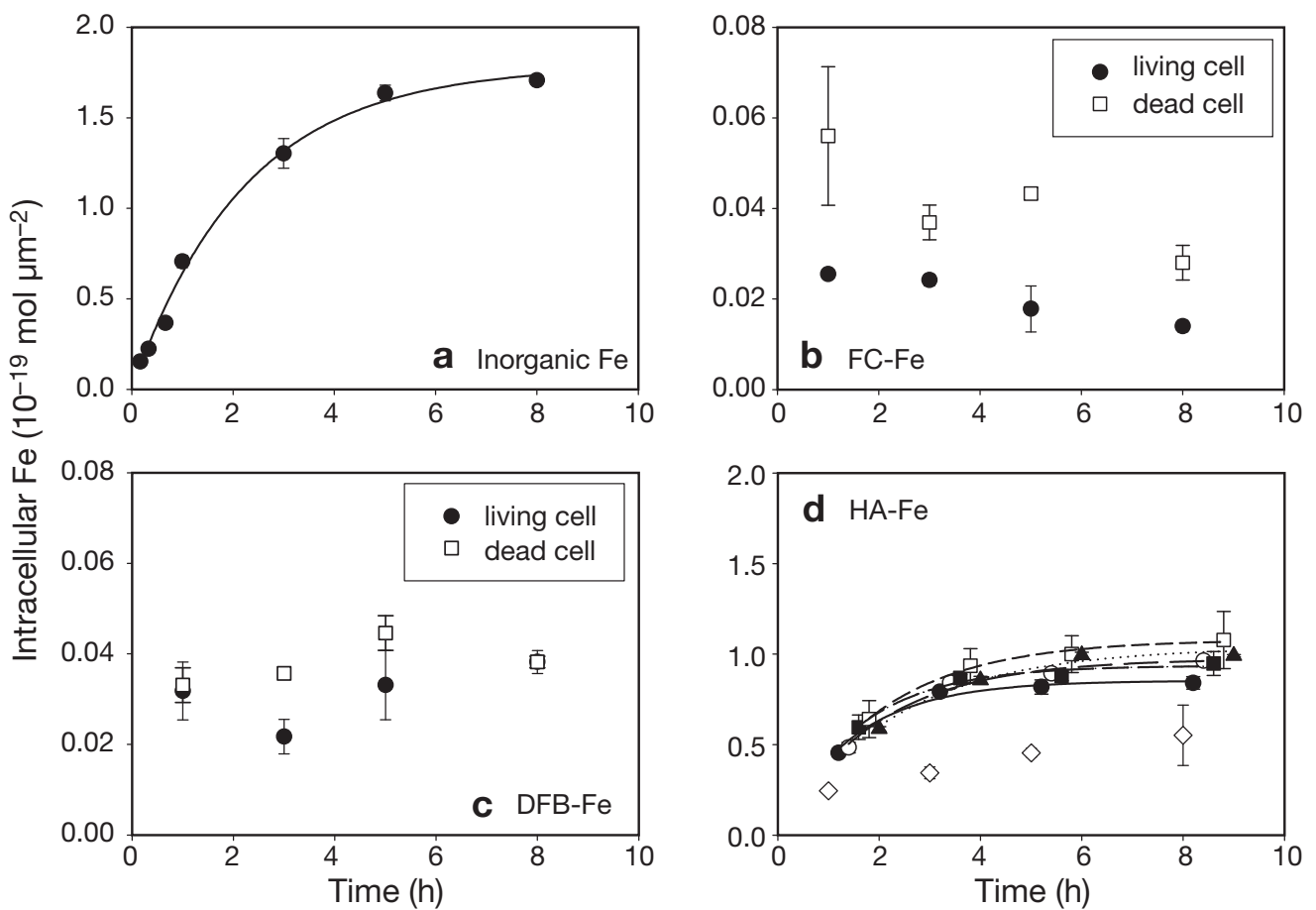

Fig. 4. Thalassiosira pseudonana. Intracellular uptake of Fe by Fe-replete T. pseudonana. (a) Inorganic Fe. (b) FC-Fe (ligand:Fe

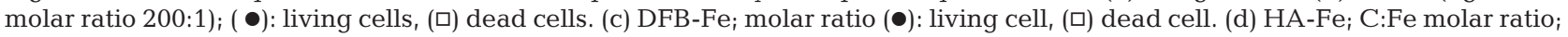
$(\bullet): 5: 1,(0): 50: 1,(\bullet): 200: 1,(\square):$ 1000:1, (\): 5000:1, $\diamond):$ 1000:1 (dead cells). Data are mean \pm range $(\mathrm{n}=2)$

the assimilation rates of fulvic Fe were $6 \times$ greater than those of EDTA Fe (100:1) and solid amorphous Fe.

Our results demonstrate that phytoplankton species accumulate HA-Fe efficiently, especially at low molar ratios of HA-C:Fe. Considering that humic acids are HMW organic matter, and most Fe in natural seawater is in the large molecular size fraction in coastal seas, HA-Fe in natural seawater may be an important Fe source for phytoplankton growth. Previously, we found that Fe solubility was controlled by the dissolved organic carbon concentration in natural seawater (Chen et al. 2004). Tani et al. (2003) and Takata et al. (2004) determined the Fe(III) hydroxide solubility in the water column of the Sea of Okhotsk and the northwestern Pacific Ocean, and found that there was a significant correlation between Fe(III) solubility and humic-type fluorescent organic matter. These studies suggest that dissolved Fe in mid-depth and deep ocean waters may be controlled primarily by Fe(III) complexation with natural organic ligands, such as dissolved humic substances released through the oxidative decomposition and transformation of biogenic organic matter, or deposited from atmospheric dust. Thus, natural organic Fe chelators, such as humic substances upwelled from deep waters, may play an important role in providing Fe for marine phytoplankton via a
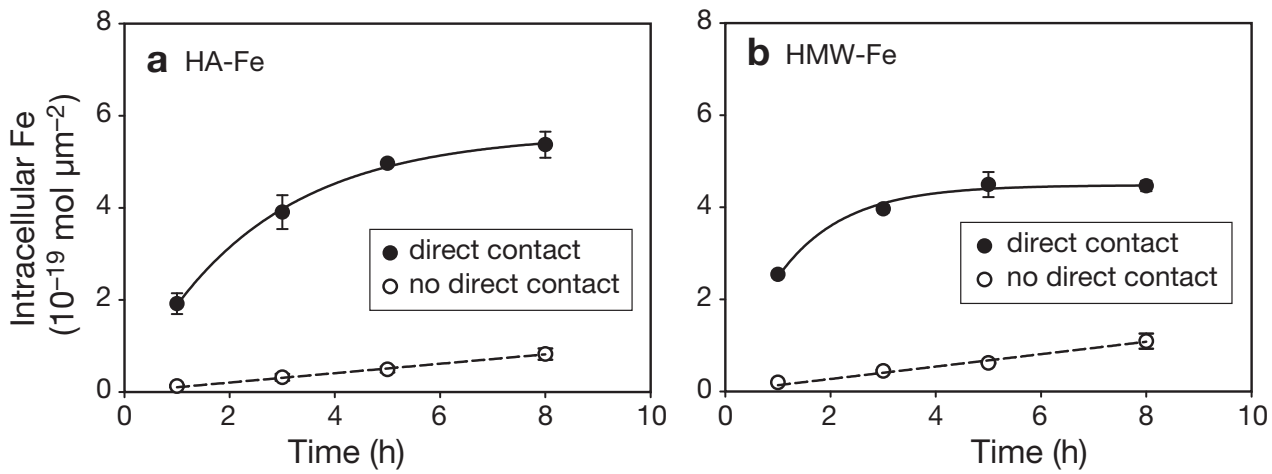

Fig. 5. Thalassiosira pseudonana. Intracellular uptake of Fe by Fe-depleted T. pseudonana with or without direct contact to the Fe complex. (a) HA-Fe; (b) natural high molecular weight (HMW) compounds with Fe. Data are mean \pm range $(n=2)$ 

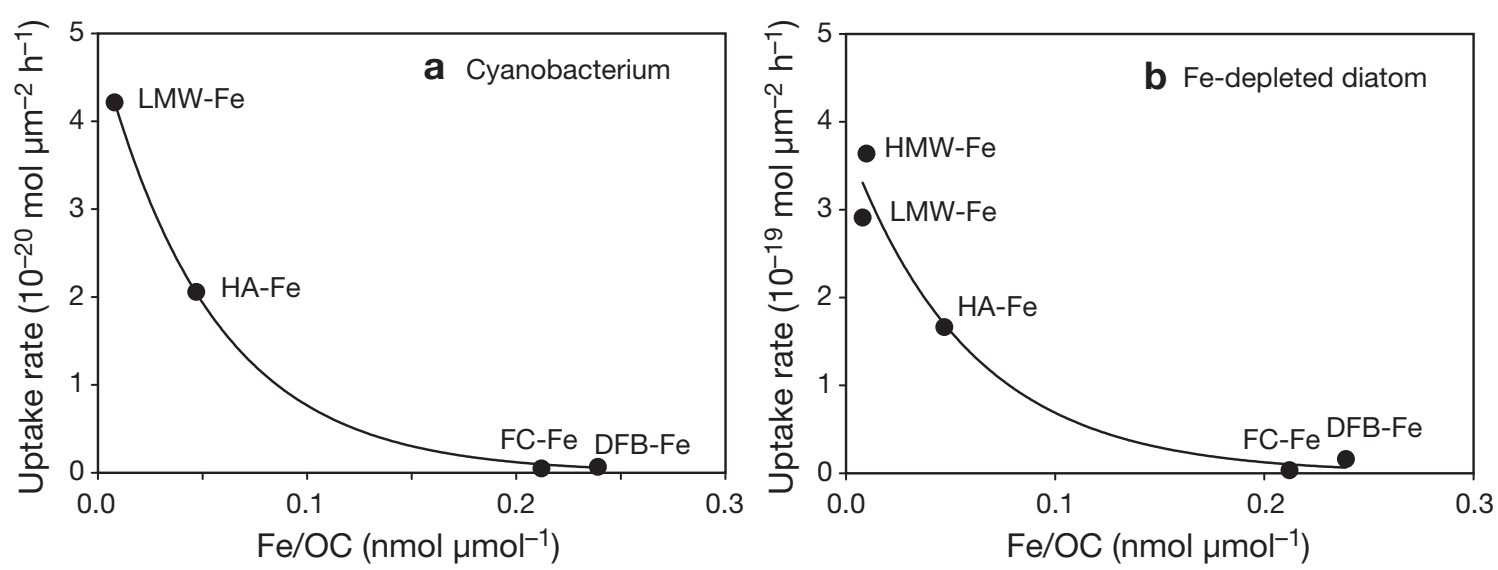

Fig. 6. (a) Synechococcus sp. CCMP 1334 and (b) Thalassiosira pseudonana. Relationship between Fe assimilation rate and Fe binding capacity of different organic ligands

cell-surface reduction process (Jones et al. 1987, Maldonado \& Price 2000) or photochemical cycling in oceanic surface waters (Johnson et al. 1994, Barbeau et al. 2001). In addition, humic and fulvic acids have high affinity for Fe to compete with Fe(III) hydrolysis in seawater (Kuma et al. 1999, Liu \& Millero 1999). In estuarine and coastal waters, humic substances may be critical in controlling Fe speciation and bioavailability. The estuarine behavior of $\mathrm{Fe}$ is intimately related to the dissolved organic matter and humic substances in river water. The humic substances (humic and fulvic acids) retard Fe(III) hydrolysis by complexation, and thus the precipitation of amorphous hydrous ferric oxide in seawater. In addition, humic substances stimulate the growth of coastal marine phytoplankton in laboratory cultures (Graneli \& Moreira 1990, Carlsson \& Graneli 1993, Kosakowska et al. 2007) and contribute to phytoplankton blooms in coastal waters (Glover 1978). Therefore, the humic acid-Fe complexes supplied by riverine input also play an important role in providing biological available Fe in coastal waters.

The initial Fe assimilation rates of HA-Fe by Synechococcus sp.and Thalassiosira pseudonana were inhibited until the HA concentration was $\sim 28 \mathrm{mg}$ organic carbon $\mathrm{l}^{-1}$ (Table 2), suggesting that inhibition of uptake by HA is not an important factor in marine systems. Our results thus support the previous assumption that humic compounds play an important role in promoting the growth of phytoplankton through metal chelation reactions (Prakash 1971). Prakash \& Rashid (1968), and Prakash et al. (1973) provided experimental evidence that HA with concentrations $<21 \mathrm{mg} \mathrm{C} \mathrm{l}^{-1}$ in culture media stimulated the growth of diatoms (Skeletonema costatum) and dinoflagellates (Gonyaulax tamarensis) by enhancing their rates of nutrient uptake and carbon assimilation, and at concentrations of $28 \mathrm{mgC}^{-1}$, the rate of carbon assimilation declined considerably.
Siderophores (DFB and FC) were the least effective species in providing $\mathrm{Fe}$ for marine phytoplankton, and in the presence of excess DFB, Fe is probably unavailable for uptake by phytoplankton and bacteria (Hutchins et al. 1999b, Wells 1999, Kuma et al. 2000). Eldridge et al. (2004) found that increasing DFB concentrations effectively limited Fe uptake ability of phytoplankton in 3 size classes $(>0.2,>1.0,>8.0 \mu \mathrm{m})$ in the South American eastern boundary current off Peru. Other studies, however, found that the marine diatom Phaeodactylum tricornutum (Soria-Dengg \& Horstmann 1995), phytoplankton communities in the subarctic Pacific (Maldonado \& Price 1999), the majority of heterotrophic marine bacteria strains (Granger \& Price 1999), and prokaryotic picoplankton (cyanobacteria) (Hutchins et al. 1999b) can utilize DFB-Fe. Hutchins et al. (1999b) further indicated that the assimilation rates of DFB-Fe by the diatoms Thalassiosira weissflogii and Skeletonema costatum were slower or similar to those of inorganic Fe. Our results demonstrate that the initial assimilation rates of siderophorebound Fe by the diatom and cyanobacterium are much slower than those of inorganic Fe(III) and HA-Fe, although the siderophore-bound Fe was available to them. The contrasting results among these studies could be due to: (1) Fe status of the cells/community, (2) ratio of organic ligand to iron, (3) excess of organic ligands in solution, and (4) photolability of organic ligands.

Fe assimilation rates decreased exponentially with increasing Fe binding capacity (Fig. 6), indicating that the availability of Fe-organic complexes to phytoplankton is related to the lability of the organic complexes. This is probably related to the relationship between stability constant $\left(\log \mathrm{K}_{\mathrm{MeL}}\right.$ ) and reduction potential (see Croot et al. 1999 and references therein) which determines the biologically mediated reduction rates of organically bound Fe (Maldonado \& Price 2001). 
Thus, the lability of the organic complex probably controls the assimilation rate of Fe by phytoplankton.

Our results also show that initial Fe assimilation rates decreased gradually with increasing molar ratio of organic ligand to $\mathrm{Fe}$, except in the case of the Fereplete diatoms, which was consistent with observations on the cyanobacterium Lyngbya majuscula by Salmon et al. (2006). Thus, comparison of Fe assimilation rates among different studies is problematic, since most of the assimilation rates previous studies were measured at other molar ratios. Even though the uptake rates of Fe bound to DFB are slower than those of inorganic $\mathrm{Fe}$, they may be biologically significant (Maldonado \& Price 2001). However, considering the low bioavailability of siderophore-bound Fe to diatoms, it is possible to manipulate Fe availability in Fe-replete coastal waters and provide a practical means for studying the influence of $\mathrm{Fe}$ on production, carbon cycling and phytoplankton species composition in nearshore waters (Hutchins et al. 1999a, Wells 1999, Wells \& Trick 2004). Adding a large excess of DFB over ambient Fe concentrations (molar ratios $2100: 1$ ) sharply curtails $\mathrm{Fe}$ uptake in natural populations in both nearshore (Wells 1999) and offshore (Wells et al. 1994) seawater. Wells \& Trick (2004) and Eldridge et al. (2004) also suggested that DFB can be used to achieve an intermediate control of Fe availability, i.e. 'titrating' available Fe to impart different degrees of Fe stress in cultures of natural populations. According to the Fe(II)s model of Shaked et al. (2005), the inhibitory effect of DFB on Fe uptake may result not only from the change in Fe speciation, but also from its ability to compete with the cells for Fe(II)s.

\section{Uptake by Fe-depleted and Fe-replete diatoms}

Cell size and cellular chl a fluorescence in Fedepleted diatoms decreased at low Fe levels, similar to observations in earlier studies (Hudson \& Morel 1990, Sunda \& Huntsman 1997, Timmermans et al. 2001a, Eldridge et al. 2004). After addition of $\mathrm{Fe}$, the initial $\mathrm{Fe}$ assimilation rates by $\mathrm{Fe}$-depleted diatoms were significantly faster than those of Fe-replete diatoms. Thus, the Fe transport system is also regulated by the nutritional status of the cells, as observed for Pleurochrysis carterae and Thalassiosira weissflogii (Harrison \& Morel 1986) (Hudson \& Morel 1990). Low $\mathrm{Fe}$ concentration limits phytoplankton growth and leads to an increasing density of $\mathrm{Fe}$ transport ligands at the cell surface. The higher concentration of these cell-surface ligands leads to faster Fe assimilation rates in Fe-depleted cells (Harrison \& Morel 1986, Hudson \& Morel 1990, Soria-Dengg et al. 2001).
Siderophore-bound Fe was taken up only by the Fe-depleted diatoms, and not by cells replete of iron. Maldonado \& Price (2001) suggested that the uptake of siderophore-bound Fe in Fe-replete cultures is more than $30 \times$ slower than in Fe-limited cultures. Maldonado \& Price (1999) determined the Fe-DFB assimilation rates at 2 stations in the California coastal upwelling, and found that only the biota at the Fe-limited stations accumulated siderophore-bound $\mathrm{Fe}$ at a significant rate, whereas uptake at the Fe-replete station was negligible. However, DFB-Fe was not taken up in the Fe-limited waters of the equatorial Pacific (Wells et al. 1994), suggesting that taxonomic composition of the plankton community may be another important factor affecting Fe-siderophore utilization.

\section{Mechanisms of organic-Fe complex uptake by diatoms}

The difference of Fe uptake rates by diatoms with and without direct contact to HMW complexes cannot be ascribed to the time lag between dissociation and diffusion out into the medium under the dialysis bag separation. A previous experiment (Chen et al. 2004) showed that Fe levels in LMW fractions were 4.3 and $2.8 \%$ for $\mathrm{HA}-\mathrm{Fe}$ and $\mathrm{HMW}$-bound $\mathrm{Fe}$, respectively. $\mathrm{Fe}$ amounts in the LMW fraction for HA in the uptake medium were $0.08 \mathrm{nM}$ and $0.06 \mathrm{nM}$ for control and treatment, respectively, and for HMW-bound $\mathrm{Fe}$, amounts in the LMW fraction were $0.06 \mathrm{nM}$ and $0.03 \mathrm{nM}$ for control and treatment, respectively. The difference between control and experimental treatments cannot account for the large difference between Fe uptake rates with or without direct contact (24- and 29-fold difference for HA-Fe and HMW-Fe, respectively). This demonstrates that the HMW-Fe complex is directly available to diatoms without dissociation of the Fe in the bulk medium.

Several mechanisms for organic-Fe complex transport have been envisioned, such as the release of Fe from the complex at the cell membrane, followed by binding of $\mathrm{Fe}$ to the membrane transporter (Hudson \& Morel 1990), or transport of the intact organic-Fe complex, followed by intracellular release of Fe and transporter (Wilhelm 1995, Braun et al. 1998). Our experiments suggest the occurrence of cell-surface sorption of organic-Fe complexes. The initial Fe assimilation rates of the HA- and HMW-Fe in direct contact with the diatom were much higher than those with the barrier of the dialysis bag. Thus, it appears that most of the HMW-Fe was taken up directly via the diatom surface without prior solution (e.g. desorption or dissociation) of Fe. Since initial assimilation rates of organic-Fe complexes decreased with increasing molar ratio of organic ligand to $\mathrm{Fe}$, and with $\mathrm{Fe}$ binding capacity, it is 
unlikely that the organic-Fe complex penetrates into the cells directly, and ligand exchange at the cell surface is the most likely process for the uptake of the organic-Fe complex. Presumably, the organic-Fe is first absorbed by the cell surface, and Fe is exchanged at the specific sites before internalization. One probable mechanism for the release of Fe from the organic complex is the biological reduction to the ferrous state (Maldonado \& Price 1999, 2000) or photoreduction (Johnson et al. 1994, Barbeau et al. 2001), which converts the tightly bound ferric complex to the loosely bound ferrous complex, from which Fe is transported intracellularly while the intact ligand is recycled. Our results are also consistent with the new kinetic model for $\mathrm{Fe}$ acquisition by diatoms (Shaked et al. 2005), which suggests that Fe(III) in the uptake medium is reduced by surface reductases to form reduced $\mathrm{Fe}$ at the cell surface, and the resultant Fe(II)s can be transported across the cell membrane (probably following oxidation) (Shaked et al. 2005) without apparent release into the medium (Kustka et al. 2005).

Acknowledgements. We thank the 3 anonymous reviewers for their very helpful and constructive comments on this work.

\section{LITERATURE CITED}

Anderson MA, Morel FMM (1982) The influence of aqueous iron chemistry on the uptake of iron by the coastal diatom Thalassiosira weissflogii. Limnol Oceanogr 27:789-813

Barbeau K, Rue EL, Bruland KW, Butler A (2001) Photochemical cycling of iron in the surface ocean mediated by microbial iron(III)-binding ligands. Nature 413:409-413

Boyd P (2004) Ironing out algal issues in the Southern Ocean. Science 304:396-397

Braun V, Hantke K, Koster W (1998) Bacterial iron transport: mechanisms, genetics, and regulations. In: Sigel A, Sigel $\mathrm{H}$ (eds) Metal ions in biological systems, Vol. 35. Iron transport and storage in microorganisms, plants, and animals. Marcel Dekker, New York, p 67-146

Bruland KW, Orians KJ, Cowen JP (1994) Reactive trace metals in the stratified central North Pacific. Geochim Cosmochim Acta 58:3171-3182

Buck KN, Lohan MC, Berger CJM, Bruland KW (2007) Dissolved iron speciation in two distinct river plumes and an estuary: implications for riverine iron supply. Limnol Oceanogr 52:843-855

> Carlsson P, Graneli E (1993) Availability of humic bound nitrogen for coastal phytoplankton. Estuar Coast Shelf Sci 36:433-447

Chen M, Wang WX (2001) Bioavailability of natural colloidbound iron to marine plankton: influences of colloidal size and aging. Limnol Oceanogr 46:1956-1967

> Chen M, Dei RCH, Wang WX, Guo LD (2003) Marine diatom uptake of iron bound with natural colloids of different origins. Mar Chem 81:177-189

Chen M, Wang WX, Guo LD (2004) Phase partitioning and solubility of iron in natural seawater controlled by dissolved organic matter. Global Biogeochem Cycles 18: GB4013 doi:10.1029/2003GB002160

Croot PL, Moffett JW, Luther GW (1999) Polargraphic de- termination of half-wave potentials for copper-organic complexes in seawater. Mar Chem 67:219-232

Eldridge ML, Trick CG, Alm MB, DiTullio GR and others (2004) Phytoplankton community response to a manipulation of bioavailable iron in HNLC waters of the subtropical Pacific Ocean. Aquat Microb Ecol 35:79-91

Glover HE (1978) Iron in marine coastal waters: seasonal variation and its apparent correlation with a dinoflagellate bloom. Limnol Oceanogr 23:534-537

Graneli E, Moreira MO (1990) Effects of river water of different origins on the growth of marine dinoflagellates and diatoms in laboratory cultures. J Exp Mar Biol Ecol 136: 89-106

Granger J, Price NM (1999) The importance of siderophores in iron nutrition of heterotrophic marine bacteria. Limnol Oceanogr 44:541-555

Guillard RRL, Ryther JH (1962) Studies on marine planktonic diatoms. I. Cyclotella nana Hustedt and Detonula confervacea (Cleve) Gran. Can J Microbiol 8:229-239

Guo L, Santschi PH (1996) A critical evaluation of cross-flow ultrafiltration techniques for sampling colloidal organic carbon in seawater. Mar Chem 55:113-127

> Guo L, Wen L, Tang D, Santschi PH (2000) Re-examination of cross-flow ultrafiltration for sampling aquatic colloids: evidence from molecular probes. Mar Chem 70:257-275

Harrison GI, Morel FMM (1986) Response of the marine diatom Thalassiosira weissflogii to iron stress. Limnol Oceanogr 31:989-997

> Hering JH, Morel FMM (1988) Humic acid complexation of calcium and copper. Environ Sci Technol 22:1234-1237

Hudson RJM, Morel FMM (1989) Distinguishing between extra- and intracellular iron in marine phytoplankton. Limnol Oceanogr 34:1113-1120

Hudson RJM, Morel FMM (1990) Iron transport in marine phytoplankton: kinetics of cellular and medium coordination reactions. Limnol Oceanogr 35:1002-1020

- Hudson RJM, Morel FMM (1993) Trace metal transport by marine microorganisms: implications of metal coordination kinetics. Deep-Sea Res I 40:129-150

Hutchins DA, Witter AE, Butler A, Luther GW III (1999a) Competition among marine phytoplankton for different chelated iron species. Nature 400:858-861

Hutchins DA, Franck VM, Brzezinski MA, Bruland KW (1999b) Inducing phytoplankton iron limitation in ironreplete coastal waters with a strong chelating ligand. Limnol Oceanogr 44:1009-1018

Johnson KS, Coale KH, Elrod VA, Tindale NW (1994) Iron photochemistry in seawater from the equatorial Pacific. Mar Chem 46:319-334

Jones GJ, Palenik BP, Morel FMM (1987) Trace metal reduction by phytoplankton: the role of plasmalemma redox enzymes. J Phycol 23:237-244

> Kosakowska A, Nedzi M, Pempkowiak J (2007) Response of the toxic cyanobacterium Microcystis aeruginosa to iron and humic substances. Plant Physiol Biochem 45:365-370

> Kuma K, Tanaka J, Matsunaga K (1999) Effect of natural and synthetic organic-Fe(III) complexes in an estuarine mixing model on iron uptake and growth of a coastal marine diatom, Chaetoceros sociale. Mar Biol 134:761-769

Kuma K, Tanaka J, Matsunaga K, Matsunaga K (2000) Effect of hydroxamate ferrisiderophore complex (ferrichrome) on iron uptake and growth of a coastal marine diatom, Chaetoceros sociale. Limnol Oceanogr 45:1235-1244

Kustka AB, Shaked Y, Milligan AJ, King DW, Morel FMM (2005) Extracellular production of superoxide by marine diatoms: contrasting effects on iron redox chemistry and bioavailability. Limnol Oceanogr 50:1172-1180 
Liu X, Millero FJ (1999) The solubility of iron hydroxide in sodium chloride solutions. Geochim Cosmochim Acta 63: 3487-3497

Maldonado MT, Price NM (1999) Utilization of iron bound to strong organic ligands by plankton communities in the subarctic Pacific Ocean. Deep-Sea Res II 46:2447-2473

Maldonado MT, Price NM (2000) Nitrate regulation of Fe reduction and transport by Fe-limited Thalassiosira oceanica. Limnol Oceanogr 45:814-826

Maldonado MT, Price NM (2001) Reduction and transport of organically bound iron by Thalassiosira oceanica. J Phycol 37:298-310

Mantoura RFC, Dickson A, Riley JP (1978) The complexation of metals with humic materials in natural waters. Estuar Coast Mar Sci 6:387-408

> Martin JH, Gordon RM (1988) Northeast Pacific iron distributions in relation to phytoplankton productivity. Deep-Sea Res 35:177-196

Nodwell LM, Price NM (2001) Direct use of inorganic colloidal iron by marine mixtrophic phytoplankton. Limnol Oceanogr 46:765-777

Nolting RF, Gerringa LJA, Swagerman MJW, Timmermans KR, de Baar HJW (1998) Fe(III) speciation in the high nutrient, low chlorophyll Pacific region of the Southern Ocean. Mar Chem 62:335-352

Poorvin L, Rinta-Kanto JM, Hutchins DA, Wilhelm SW (2004) Viral release of iron and its bioavailability to marine plankton. Limnol Oceanogr 49:1734-1741

Prakash A (1971) Terrigenous organic matter and coastal phytoplankton fertility. In: Costlow JD (ed), Fertility of the sea, Vol. 2. Gordon \& Breach, New York, p 351-368

Prakash A, Rashid MA (1968) Influence of humic substances on the growth of marine phytoplankton: dinoflagellates. Limnol Oceanogr 13:598-606

Prakash A, Rashid MA, Jensen A, Subba Rao DV (1973) Influence of humic substances on the growth of marine phytoplankton: diatoms. Limnol Oceanogr 18:516-524

Rose AL, Waite TD (2003) Kinetics of iron complexation by dissolved natural organic matter in coastal waters. Mar Chem 84:85-103

Rue EL, Bruland KW (1995) Complexation of iron(III) by natural organic ligands in the Central North Pacific as determined by a new competitive ligand equilibration/adsorptive cathodic stripping voltammetric method. Mar Chem 50:117-138

Rue EL, Bruland KW (1997) The role of organic complexation on ambient iron chemistry in the equatorial Pacific Ocean and the response of a mesoscale iron addition experiment. Limnol Oceanogr 42:901-910

Salmon TP, Rose AL, Neilan BA, Waite TD (2006) The FeL model of iron acquisition: nondissociative reduction of ferric complexes in the marine environment. Limnol Oceanogr 51:1744-1754

Santana-Casiano JM, González-Dávila M, Laglera LM, PérezPeña J, Brand L, Millero FJ (1997) The influence of zinc, aluminum and cadmium on the uptake kinetics of iron by algae. Mar Chem 59:95-111

Shaked Y, Kustka AB, Morel FMM (2005) A general kinetic model for iron acquisition by eukaryotic phytoplankton. Limnol Oceanogr 50:872-882

Sholkovitz ER, Boyle EA, Price NB (1978) The removal of dissolved humic acids and iron during estuarine mixing. Earth Planet Sci Lett 40:130-136

Editorial responsibility: Matthias Seaman, Oldendorf/Luhe, Germany
Soria-Dengg S, Horstmann U (1995) Ferrioxamines B and E as iron sources for the marine diatom Phaeodactylum tricornutum. Mar Ecol Prog Ser 127:269-277

Soria-Dengg S, Reissbrodt R, Horstmann U (2001) Siderophores in marine coastal waters and their relevance for iron uptake by phytoplankton: experiments with the diatom Phaeodactylum tricornutum. Mar Ecol Prog Ser 220:73-82

Sunda WG, Huntsman SA (1995) Iron uptake and growth limitation in oceanic and coastal phytoplankton. Mar Chem 50:189-206

Sunda WG, Huntsman SA (1997) Interrelated influence of iron, light, and cell size on growth of marine phytoplankton. Nature 390:389-392

Takata H, Kuma K, Iwade S, Yamajyoh Y and others (2004) Spatial variability of iron in the surface water of the northwestern North Pacific Ocean. Mar Chem 86:139-157

Tani H, Nishioka J, Kuma K, Takata H, Yamashita Y, Tanoue E, Midorikawa T (2003) Iron (III) hydroxide solubility and humic-type fluorescent organic matter in the deep water column of the Okhotsk Sea and the northwestern North Pacific Ocean. Deep-Sea Res I 50:1063-1078

Timmermans KR, Davey MS, van der Wagt D, Snoek J and others (2001a) Co-limitation by iron and light of Chaetoceros brevis, $C$. dichaeta and C. calcitrans (Bacillariophyceae). Mar Ecol Prog Ser 217:287-297

Timmermans KR, Gerringa LJA, de Baar HJW, van der Wagt B, Veldhuis MJW, de Jong JTM, Croot PL (2001b) Growth rates of large and small Southern Ocean diatoms in relation to availability of iron in natural seawater. Limnol Oceanogr 46:260-266

- Trick CG (1989) Hydroxamate-siderophore production and utilization by marine eubacteria. Curr Microbiol 18: 375-378

> Trick CG, Wilhelm SW (1995) Physiological changes in the coastal marine cyanobacterium Synechococcus sp. PCC 7002 exposed to low ferric iron levels. Mar Chem 50: $207-217$

> van den Berg CMG (1995) Evidence for organic complexation of iron in seawater. Mar Chem 50:139-157

> Wang WX, Dei RCH (2003) Bioavailability of iron complexed with organic colloids to the cyanobacteria Synechococcus and Trichodesmium. Aquat Microb Ecol 33:247-259

Wells ML (1999) Manipulating iron availability in nearshore waters. Limnol Oceanogr 44:1002-1008

- Wells ML, Trick CG (2004) Controlling iron availability to phytoplankton in iron-replete coastal waters. Mar Chem 86:1-13

Wells ML, Price NM, Bruland KW (1994) Iron limitation and cyanobacterium synechococcus in equatorial Pacific waters. Limnol Oceanogr 39:1481-1486

Wilhelm SW (1995) Ecology of iron-limited cyanobacteria: a review of physiological responses and implications for aquatic systems. Aquat Microb Ecol 9:295-303

Wilhelm SW, Trick CG (1994) Iron-limited growth of cyanobacteria: multiple siderophore production is a common response. Limnol Oceanogr 39:1979-1984

Winkelmann G (1991) Specificity of iron transport in bacteria and fungi. In: Winkelmann G (ed) Handbook of microbial iron chelates. CRC Press, Boca Raton, FL, p 65-106

Wu J, Luther GW (1995) Complexation of Fe(III) by natural organic ligands in the Northwest Atlantic Ocean by a competitive ligand equilibration method and a kinetic approach. Mar Chem 50:159-177

Submitted: October 26, 2007; Accepted: May 22, 2008

Proofs received from author(s): July 21, 2008 